\title{
EFEKTIFITAS PENERAPAN MODEL PEMBELAJARAN KOLABORASI TALKING STICK DAN TEBAK KATA TERHADAP HASIL BELAJAR SISWA PADA PELAJARAN IPA DI MADRASAH IBTIDAIYAH BELITANG MULYA
}

\author{
SRI ENGGAR KENCANA DEWI ${ }^{1 *}$, RATIH PURNAMA PERTIWI ${ }^{2}$ \\ STKIP NURUL HUDA OKU TIMUR \\ *E-mail: enggar@stkipnurulhuda.co.id
}

\begin{abstract}
Abstrak
Berdasarkan observasi penelitian awal, proses pembelajaran seperti ini juga terjadi pada mata pelajaran IPA di Madarasah Ibtidaiyah Belitang Mulya. Siswa tidak begitu antusias mengikuti pembelajaran disebabkan guru tidak menggunakan model pembelajaran yang bervariasi. Tujuan penelitian ini mengetahui efektiftas penerapan model kolaborasi talking stick dan tebak kata terhadap hasil belajar siswa pada pelajaran IPA kelas V di Madrasah Ibtidaiyah. penelitian ini menggunakan penelitian eksperimen jenis pre-eksperimental design yang dilakukan hanya pada satu kelas saja tanpa adanya kelas pembanding atau disebut dengan One-Group Pretest-Posttest Design. Hasil penelitian data pretest hasil belajar siswa kelas $\mathrm{V}$ diperoleh rata-rata 70,4 , dan hasil Posttest sesudah menerapkan model pembelajaran kolaboratif Talking Stick dan Tebak kata mempunyai nilai tertinggi adalah 90 dan nilai terendah yaitu 50, serta rata-ratanya adalah 70,4. penerapan model pembelajaran kolaboratif talking stick dan tebak kata, dan sesudah penerapan model pembelajaran kolaboratif talking stick dan tebak kata terlihat ada perubahan yang lebih baik dan efektif utuk digunakan.
\end{abstract}

Kata kunci : kolaboratif talking stick, hasil belajar

\section{PENDAHULUAN}

Tujuan akhir Anda adalah untuk membuat makalah yang sesuai dengan aturan baku jurnal Titian IImu. Untuk hal-hal yang tidak tercantum di panduan ini, silahkan mengacu pada informasi yang telah Anda dapatkan pada aturan penulisan ilmiah. Makalah dipersiapkan dalam bentuk softcopy dengan format ukuran kertas A4. Batas tepi: atas $=2,54 \mathrm{~cm}$, bawah $=2,54 \mathrm{~cm}$, sisi $=1,9 \mathrm{~cm}$. Ukuran paragraf menjorok adalah $0,35 \mathrm{~cm}$.

Tipe Ukuran dan Jenis huruf: ikuti ukuran yang telah dicantumkan dalam Tabel 1. Untuk diperhatikan pada jenis ukuran, 1 point adalah sekitar $0,35 \mathrm{~mm}$. Jenis huruf lebih disarankan menggunakan Arial 10. Tiap paragraf diatur rata kiri-kanan. Pada halaman terakhir makalah Anda, atur panjang lebarnya agar sama besar. Gunakan tanda hubung otomatis dan pemeriksa ejaan (bila tersedia).

\section{METODE/EKSPERIMEN}

Penelitian ini menggunakan penelitian eksperimen jenis pre-eksperimental design yang dilakukan hanya pada satu kelas saja tanpa adanya kelas pembanding atau disebut dengan One-Group Pretest-Posttest Design. Sugiyono (2017:111) menggambarkan One-Group Pretest-Posttest Design, sebagai berikut: 


\section{$\mathrm{O}_{1} \times \mathrm{O}_{2}$}

Keterangan :

$\mathrm{O}_{1}=$ nilai pretest $($ sebelum diberi diklat)

$\mathrm{O}_{2}=$ nilai posttest ( setelah diberi diklat)

$X=$ perlakuan atau treatmen

Pengaruh perlakuan diklat $=\left(\mathrm{O}_{2}-\mathrm{O}_{1}\right)$

Penelitian ini menggunakan dua variabel yaitu variabel bebas dan variabel terikat. Variabel bebas sering disebut stimulus atau prediktor, yaitu variabel yang mempengaruhi atau yang menjadi sebab perubahannya atau timbulnya variabel yang dependen (terikat).Variabel bebas dalam penelitian ini adalah pembelajaran tematik-integratif dengan pendekatan saintifik. Variabel terikat sering disebut vaiabel output, kriteria, atau konsekuen, yaitu variabel yang dipengaruhi atau yang menjadi akibat dari variabel bebas. Variabel terikat dalam penelitian ini adalah hasil belajar siswa.

Populasi adalah keseluruhan gejala atau satuan yang ingin diteliti. Maka populasi dalam penelitian ini yaitu seluruh siswa dan siswi kelas IV dengan jumlah 42 orang, dapat dilihat tabel dibawah ini.

TABEL 1

Populasi Penelitian

\begin{tabular}{|c|c|c|c|c|}
\hline No & \multicolumn{1}{|c|}{ Kelas } & Laki-Laki & Perempuan & Jumlah \\
\hline 1. & V. A & 13 & 12 & 25 \\
\hline \multicolumn{4}{|c|}{ TOTAL } & 25 \\
\hline
\end{tabular}

Sumber: TU MI Alhikmah Purwodadi dan MI Nurul Huda Srimulyo

Sampel dalam Penelitian ini diambil menggunakan Sampling jenuh, sampling jenuh adalah mengambil seluruh anggota populasi sebagai sampel. untuk menentukan kelas eksperimen dan kelas kontrol, kelas eksperimen adalah kelas yang diberi perlakuan sedangkan kelas kontrol adalah kelas yang tidak diberikan perlakuan (Sugiyono, 2008)

Sampel dalam populasi ini adalah 25 orang. Menurut Suharsimi Arikunto jika subjeknya kurang dari 100 lebih baik di ambil semua, dan jika subjeknya lebih dari 100 maka sampelnya diambil antara $10 \%-15 \%$ atau $20 \%-25 \%$ atau lebih (Arikunto, 2010).

Pengumpulan data yang dilakukan dalam penelitian ini adalah dengan menggunakan tes teknik ini digunakan untuk mendapatkan informasi tentang hasil belajar siswa dengan cara memberikan serangkaian soal pretest dan posttest kepada peserta didik kelas V MI Belitang Mulya . Teknik Observasi merupakan suatu pengamatan langsung terhadap siswa. Observasi atau pengamatan sebagai alat penilaian banyak digunakan untuk mengukur tingkah laku individu ataupun proses 
terjadinya suatu kegiatan yang dapat diamati, baik dalam situasi yang sebenarnya maupun dalam situasi buatan. Adapun teknik observasi yang akan digunakan dalam penelitian ini untuk mengetahui keadaan objek secara langsung serta proses pembelajaran yang berlangsung.

Pada uji asumsi, akan dilakukan uji normalitas (sebelum perlakuan) dan data akhir (setelah perlakuan) secara univariat (masing-masing). Pengujian tersebut dilakukan dengan menggunakan SPSS. Adapun pengambilan keputusan di sini jika nilai signifikansi $(s i g)<$ dari probabilitas $\alpha 0,05$ maka Ho ditolak dan Ha diterima.

\section{HASIL DAN PEMBAHASAN}

Hasil belajar peserta didik dilihat dari hasil perolehan nilai setelah dilakukan tes awal (pre-test) dan tes akhir (post-test). Penelitian menggunakan metode tes untuk mendapatkan data yang diperlukan dalam penelitian ini. Data dalam penelitian ini adalah data yang diperoleh dari nilai siswa hasil penerapan model pembelajaran kolaboratif talking stick dan tebak kata yang peneliti lakukan dalam pembelajaran Ilmu Pengetahuan Alam tema 4 seb tema 1 pembelajaran 1.

Tabel 1.1

\section{NILAI PRETEST SISWA MI AL-HIKMAH PURWODADI KELAS V}

\begin{tabular}{ccc}
\hline NO & NAMA & $\begin{array}{c}\text { SKOR } \\
\text { PRETEST }\end{array}$ \\
\hline 1 & SISWA 1 & 70 \\
2 & SISWA 2 & 50 \\
3 & SISWA 3 & 70 \\
4 & SISWA 4 & 20 \\
5 & SISWA 5 & 30 \\
6 & SISWA 6 & 40 \\
7 & SISWA 7 & 10 \\
8 & SISWA 8 & 70 \\
9 & SISWA 9 & 60 \\
10 & SISWA 10 & 20 \\
11 & SISWA 11 & 20 \\
12 & SISWA 12 & 20 \\
13 & SISWA 13 & 20 \\
14 & SISWA 14 & 60 \\
15 & SISWA 15 & 20 \\
16 & SISWA 16 & 50 \\
17 & SISWA 17 & 70 \\
18 & SISWA 18 & 50 \\
19 & SISWA 19 & 60 \\
20 & SISWA 20 & 50 \\
21 & SISWA 21 & 50 \\
22 & SISWA 22 & 10 \\
23 & SISWA 23 & 40 \\
24 & SISWA 24 & 60 \\
25 & SISWA 25 & 40 \\
& Rata-Rata & 41,5 \\
\hline
\end{tabular}

Tabel $1.1 \mathrm{di}$ atas menunjukkan bahwa nilai hasil belajar siswa kelas $\mathrm{V}$ sebelum menerapkan 
model pembelajaran kolaboratif talking stick dan tebak kata mempunyai nilai tertinggi adalah 70 dan nilai terendah yaitu 10 , serta rata-ratanya adalah 41,5 .

Tabel 1.2

NILAI POST TEST SISWA MI AL-HIKMAH PURWODADI KELAS V

\begin{tabular}{ccc}
\hline NO & NAMA & $\begin{array}{c}\text { SKOR } \\
\text { POSTTEST }\end{array}$ \\
\hline 1 & SISWA 1 & 80 \\
2 & SISWA 2 & 80 \\
3 & SISWA 3 & 70 \\
4 & SISWA 4 & 80 \\
5 & SISWA 5 & 70 \\
6 & SISWA 6 & 60 \\
7 & SISWA 7 & 60 \\
8 & SISWA 8 & 80 \\
9 & SISWA 9 & 80 \\
10 & SISWA 10 & 60 \\
11 & SISWA 11 & 70 \\
12 & SISWA 12 & 60 \\
13 & SISWA 13 & 70 \\
14 & SISWA 14 & 70 \\
15 & SISWA 15 & 70 \\
16 & SISWA 16 & 70 \\
17 & SISWA 17 & 80 \\
18 & SISWA 18 & 90 \\
19 & SISWA 19 & 60 \\
20 & SISWA 20 & 60 \\
21 & SISWA 21 & 50 \\
22 & SISWA 22 & 80 \\
23 & SISWA 23 & 70 \\
24 & SISWA 24 & 70 \\
25 & SISWA 25 & 70 \\
& Rata-Rata & 70,4 \\
\hline & &
\end{tabular}

Data di atas terlihat bahwa nilai hasil belajar siswa kelas $\mathrm{V}$ sesudah menerapkan model pembelajaran kolaboratif Talking Stick dan Tebak kata mempunyai nilai tertinggi adalah 90 dan nilai terendah yaitu 50 , serta rata-ratanya adalah 70,4 .

Uji Normalitas menguji normalitas pada hasil pretest dan posttes dengan menggunakan uji normalitas Shapiro-Wilk dengan bantuan SPSS. 
EFEKTIFITAS PENERAPAN MODEL PEMBELAJARAN... | 17

Tabel 1.3

Hasil Uji Normalitas dengan Shapiro-Wilk

Tests of Normality

\begin{tabular}{lcrrrrr}
\hline & \multicolumn{3}{c}{ Kolmogorov-Smirnova $^{\mathrm{a}}$} & \multicolumn{3}{c}{ Shapiro-Wilk } \\
\hline \multirow{3}{*}{ pretest } & Statistic & \multicolumn{1}{c}{ Df } & \multicolumn{1}{c}{ Sig. } & Statistic & $\mathrm{df}$ & \multicolumn{1}{c}{ Sig. } \\
posttest & .185 & 25 & .026 & .902 & 25 & .021 \\
& .203 & 25 & .009 & .908 & 25 & .028
\end{tabular}

a. Lilliefors Significance Correction

Berdasarkan hasil uji normalitas dengan dapat dijelaskan bahwa apabila hasil signifikansi(sig) > dari a 0,05 maka data dapat dikatakan normal. Salam tabel uji normalitas diatas kita membaca nya pada kolom Shapiro Wilk karena disini peneliti menggunakan uji normalitas Shapiro Wilk nilai pretest memiliki signifikansi (sig) adalah 0,021 dan posttest memiliki signifikansi (sig) 0,028, jadi dapat disimpulkan bahwasannya jika nilai Sig $>$ dari $\alpha$ 0,05 maka data tersebut dikatakan normal.

Paired simple $t$ test digunakan untuk menjawab rumusan masalah dalam penelitian. Berikut hasil output dari SPSS.

Tabel

Hasil Uji Paired Simple Test

Paired Samples Test

\begin{tabular}{|c|c|c|c|c|c|c|c|c|c|}
\hline & \multicolumn{5}{|c|}{ Paired Differences } & \multirow[b]{3}{*}{$\mathrm{T}$} & \multirow[b]{3}{*}{ df } & \multirow{3}{*}{$\begin{array}{l}\text { Sig. (2 } \\
\text { tailed) }\end{array}$} \\
\hline & & \multirow[b]{2}{*}{ Mean } & \multirow{2}{*}{$\begin{array}{c}\text { Std. } \\
\text { Deviation }\end{array}$} & \multirow{2}{*}{$\begin{array}{c}\text { Std. Error } \\
\text { Mean }\end{array}$} & \multicolumn{2}{|c|}{$\begin{array}{l}95 \% \text { Confidence } \\
\text { Interval of the } \\
\text { Difference }\end{array}$} & & & \\
\hline & & & & & Lower & Upper & & & \\
\hline Pair 1 & $\begin{array}{l}\text { pretest - } \\
\text { posttest }\end{array}$ & 28.000 & 20.207 & 4.041 & -36.341 & -19.659 & -6.928 & 24 & .000 \\
\hline
\end{tabular}

Berdasarkan tabel di atas dapat diketahui nilai pretest dan postest dengan nilai rata- rata 28.000 dengan standar deviasi 20.207 dengan menggunakan tingkat kepercayaan 95\% signifikansi $5 \%$ atau 0,05 . Jadi dapat dilihat hasil signifikansi (sig) $0,00<$ dari 0,05 , maka dapat disimpulkan bahwa data diatas dapat dikatakan baik karena hasil sig $0,00<$ dari 0,05.

Regresi linier ini digunakan untuk menjawab rumusan masalah dalam penelitian ini, berikut hasil dari uji regresi linier sederhana. 
Tabel

Hasil dari Regresi Linier Sederhana

\begin{tabular}{|c|c|c|c|c|c|c|}
\hline \multicolumn{7}{|c|}{ ANOVA $^{b}$} \\
\hline \multirow{2}{*}{\multicolumn{2}{|c|}{ Model }} & Sum of & & & & \\
\hline & & Squares & $d f$ & Mean Square & $\mathrm{F}$ & Sig. \\
\hline \multirow[t]{3}{*}{1} & Regression & 552.374 & 1 & 552.374 & 1.366 & $.000^{\mathrm{a}}$ \\
\hline & Residual & 9303.626 & 23 & 404.505 & & \\
\hline & Total & 9856.000 & 24 & & & \\
\hline
\end{tabular}

a. Predictors: (Constant), $\mathrm{X}$

b. Dependent Variable: $Y$

Berdasarkan tabel hasil regresi linier sederhana diatas dapat kita lihat diketahui nilai $s i g<$ dari a 0,05 itu dapat dikatakan adanya keefektivan dari model pembelajaran kolaboratif talking stick dan tebak kata terhadap hasil belajar siswa. Hal ini ditunjukkan bahwa nilai $\operatorname{Sig}(0,00<$ dari probabilitas 0,05 dengan persamaan linier sederhana 0,05 maka dapat disimpulkan Ho ditolak dan Ha diterima. Dengan begitu dalam penelitian ini ada keefektivan model pembelajaran kolaboratif talking stick dan tebak kata terhadap hasil belajar siswa.

\section{Pembahasan}

Penelitian ini bertujuan untuk menguji efektifitas penerapan model pembelajaran kolaboratif talking stick dan tebak kata terhadap hasil belajar siswa. Berdasarkan hasil uji nya bahwa penerapan model pembelajaran kolaboratif talking stick dan tebak kata efektif dengan hasil belajar siswa di madrasah Ibtidaiyah Belitang Mulya.

Dari data nilai hasil belajar siswa dari sebelum penerapan model pembelajaran kolaboratif talking stick dan tebak kata, dan sesudah penerapan model pembelajaran kolaboratif talking stick dan tebak kata terlihat ada perubahan yang lebih baik. Dan jika dikategorikan dalam tabel keefektifan dibawah ini:

Tabel Ukuran Efektivitas menurut Litbang Depdagri

\begin{tabular}{cl}
\hline Rasio Efektivitas & Tingkat Capaian \\
\hline Dibawah 40 & Sangat tidak efektif \\
$40-59,99$ & Tidak efektif \\
$60-79,99$ & Cukup efektif \\
Diatas 80 & Sangat efektif \\
\cline { 2 - 2 } Litbang Depdagri, 1991 &
\end{tabular}

Nilai posttest yang diperoleh rata-rata nilai 71,04 dengan nilai terbesar 90 . Menurut tabel Litbang Depdagri (1991) maka dalam kategori tabel kefektifan bahwasannya model pembelajaran kolaboratif talking stick dan tebak kata sangatlah efektif untuk hasil belajar siawa. Jadi kefektivan suatu model pembelajaran kolaboratif talking stick dan tebak kata tersebut dapat dikatakan efektif apabila terdapat perubahan hasil belajar siswa sebelum dan sesudah penerapan model pembelajaran kolaboratif, sebagai guru mampu menempatkan dan menggunakan model pembelajaran tersebut 
EFEKTIFITAS PENERAPAN MODEL PEMBELAJARAN... | 19

dengan baik dan benar.

\begin{tabular}{ccc}
\hline No & Uraian & Keterangan \\
\hline 1 & Uraian 1 & Keterangan \\
2 & Uraian 2 & Keterangan \\
3 & Uraian 3 & Keterangan \\
4 & Uraian 4 & Keterangan \\
5 & Uraian 5 & Keterangan \\
\hline
\end{tabular}

\section{PENUTUP}

Berdasarkan hasil penelitian dan hasil analisis data yang telah dilakukan, dapat disimpulkan observasi penelitian awal, proses pembelajaran seperti ini juga terjadi pada mata pelajaran IPA di Madarasah Ibtidaiyah Belitang Mulya. Siswa tidak begitu antusias mengikuti pembelajaran disebabkan guru tidak menggunakan model pembelajaran yang bervariasi. Tujuan penelitian ini mengetahui efektiftas penerapan model kolaborasi talking stick dan tebak kata terhadap hasil belajar siswa pada pelajaran IPA kelas V di Madrasah Ibtidaiyah. penelitian ini menggunakan penelitian eksperimen jenis pre-eksperimental design yang dilakukan hanya pada satu kelas saja tanpa adanya kelas pembanding atau disebut dengan One-Group Pretest-Posttest Design. Hasil penelitian data pretest hasil belajar siswa kelas $V$ diperoleh rata-rata 70,4 , dan hasil Posttest sesudah menerapkan model pembelajaran kolaboratif Talking Stick dan Tebak kata mempunyai nilai tertinggi adalah 90 dan nilai terendah yaitu 50 , serta rata-ratanya adalah 70,4 . penerapan model pembelajaran kolaboratif talking stick dan tebak kata, dan sesudah penerapan model pembelajaran kolaboratif talking stick dan tebak kata terlihat ada perubahan yang lebih baik dan efektif utuk digunakan.

\section{UCAPAN TERIMAKASIH}

Terimakasih kepada Ketua STKIP Nurul Huda OKUT, Ketua LPPM STKIP Nurul Huda OKUT, Anggota Jurnal Jemari STKIP Nurul Huda OKUT, Kepala sekolah MI Belitang Mulya beserta jajarannya, Dan Dosen-Dosen STKIP Nurul Huda OKUT.

\section{DAFTAR PUSTAKA}

Alma, Bukhori. (2008). Guru Profesional Menguasai Metode Dan Terampil Mengajar. Bandung: Alfa Beta

Arikunto, Suharsimi. (2003). Prosedur Penelitian. Jakarta: Rineka Cipta.

Budiningsih, Asri. (2005). Belajar dan Pembelajaran. Jakarta: Rineka Cipta.

Daryanto. (2010). Belajar dan Mengajar. Bandung: Yrama Widya.

Droid, Zaky. (2011). Pengertian dan Definisi Belajar. Bandung: Cipta Karya.

Eko, Ras. (2011). Model Pembelajaran Tebak Kata . Http://Raseko.Blogspot.com, Diakses: 23 April 2019.

Ginnis. (2008). Model-model Pembelajaran. Surabaya: Cipta Karya.

Herdian. (2009). Model Pembelajaran Talking Stick. Http://Herdy07 wordpress.com, Diakses: 23 April 2019.

Purwanto. (2010). Evaluasi Hasil Belajar. Yogyakarta: Pustaka Pelajar.

Sardiman. (2001). Interaksi dan Motivasi Belajar Mengajar. Jakarta: Raja Grafindo Persada.

Slameto. (2010). Belajar dan Faktor-faktor yang Mempengaruhinya. Jakarta: Rineka Cipta.

Sudijono. (2009). Pengantar Statistik Pendidikan. PT Raja Grafindo Persada : Jakarta.

Sugiyono. (2010). Metode Penelitian Kuantitatif dan Kualitatif dan R dan D. Bandung: Alfabeta. 
20 | Jemari: Jurnal Edukasi Madrasah Ibtidaiyah, Vol. 2 No. 1, Halaman: 13 - 20, January, 2020

Sugiyono. (2008). Statistika Untuk Penelitian. Bandung: Alfabeta.

Suherman, Erman dan Udin S .(2003). Strategi Pembelajaran Matematika Kontemporer.Bandung : FMIPA Universitas Pendidikan Indonesia.

Sutikno, M.Sobry. (2013). Belajar dan Pembelajaran. Lombok: Holistica.

Tarmizi. (2010). Talking stick. Http://tarmizi.wordpress.com, Diakses: 24 April 2019.

Widodo, Rahmad. (2009). Model Pembelajaran Talking Stick. Http://wywid.wordpress. Com, Diakses: 24 April 2019. 